\title{
Professional, Spectator, and Olympic Sports in the Context of the Terms Spiritualism and Spirituality, and in the Context of Normative Ethics
}

Authors' contribution:

A) conception and design of the study

B) acquisition of data

C) analysis and interpretation of data

D) manuscript preparation

E) obtaining funding

\section{Jerzy Kosiewicz}

Josef Pilsudski University of Physical Education in Warsaw, Poland
The author has used - in his paper - two different expressions related to spirituality in its entirety: that is, spirituality (the spiritual sphere in superficial sense and meaning) and spiritualism (the spiritual sphere in deep sense and meaning). The author presented selected different definitions and manifestations of spirituality and spiritualism.

The considerations on so-called "spirituality" - related to different phenomena of culture - without notions of spirituality and spiritualism - are a testimony to ordinary, typical common sense thinking only.

Author would like to underline, that contemporary professional, spectator sport and the Olympic Games are only a mass culture phenomenon. A phenomenon of mass culture can be only a mirror of superficial spirituality, but not a testimony to spiritualism (that is, deep spirituality).

The ancient Olympic Games - in contrast to the concept of Coubertin's idea of Olympism - were a manifestation of deep spirituality, that is spiritualism. The Greek Games were based on an internal unity between religiosity, art and sport.

keywords spirituality, spiritualism, sport, Olympic Games, art and religiosity

\section{Superficial vs. deep spirituality}

Throughout the traditional and contemporary literature that concentrates on problems related to spirituality in an individual and social dimension, there is just one English expression (derived from Latin) that is used, i.e. spirituality. It includes manifestations of superficial (common) spirituality as well as deep spirituality - one that transcends patterns of mass culture and goes beyond ordinary experiences. The fact that the same expression has been used to describe two distinctly different forms of spirituality has caused substantive misunderstandings. Therefore, I have introduced an expression, and at the same time a distinction of a similar source-language provenance - spiritualism - which characterizes phenomenal and psychological experiences relevant to deep spirituality in given substantive contexts. 
Regarding the relationship between sports and the indicated forms of spirituality, I have focused on the most prevalent (in the culturally diverse societies of the West and the East) disciplines (accepted in both these cultures) of competitive, high performance, professional, spectator, and in particular, Olympic sports. I did not take into account little known or specific sport disciplines that arouse little interest in other societies (e.g., motorbike racing on ice in Russia or Scandinavia, or Finnish baseball).

I have also omitted various types of physical and tourist recreational activities and other forms of activity related to physical culture, both popular and those characteristic of local and less preferential communities. This refers to activities outside religious foundations (e.g., games of Scottish highlanders G. Jarvie), including those that are para-religious (e.g., the Western form of Indian yoga, Japanese kendo as a combat sport - Cardiff) and religious (e.g., much diversified pilgrimages in Europe and in countries of the Middle and Far East).

This paper intends to show that spiritualism, in philosophical and religious terms (or in a more narrow sense - in theological terms), does not correspond (with a few exceptions) to the affirmation of sensuality, physicality, physical fitness, or physical perfectionism, juxtaposed against the aforementioned forms of competitive sports. The exceptions are - partially because of the religious origins of the ancient Olympic Games - sports of the native cultures of North, Central, and South America in the pre-Columbian era; the competitive Maori sports of the New Zealand Aborigines (Pawlik, 2010, pp. 51-56; Pawlik, 2011, pp. 111-116); or even martial arts presentations and competitions. In other words, it may be presumed that the aforementioned forms of competitive sports (i.e., contemporary forms of high performance, professional, spectator, and Olympic sports) are primarily associated with the manifestations and characteristics of superficial spirituality (common, generic) that barely, if at all, correspond to the properties assigned to spiritual experience and higher-tier spirituality - in other words - with deep spirituality.

\section{Spirituality and spiritualism}

The definitions of spirituality and spiritualism are borrowed from Latin (spiritus meaning breath, derived from spirale - to blow or breathe) ${ }^{1}$. The term that is closely related, "spirituality", causes, in my opinion, a linguistic and semiotic dissonance, and a kind of substantive incoherence. In the first instance, this incoherence refers to the ambiguity of the term. Secondly, with its indeterminate nature and lack of cognitive precision, it resonates some kind of ignorance in that it classifies every kind of spirituality into one category, as if it were a key that could be applied to many diverse psychic phenomena (too diverse and too many).

Katarzyna Skrzypińska comments on spirituality in a similar way. In her opinion, this concept has for centuries been widely perceived as an enigmatic phenomenon. Its manifestations related to the belief in supernatural phenomena, so-called peak experiences, as well as transcendent and religious ideas. These beliefs comprised cognitive, emotional, and behavioral elements. It is difficult to specify the indicated concept, especially as these phenomena, states of mind, ideas and experiences of non-confessional, paraconfessional, and confessional nature, were described for the most part in (non-scholarly) Latin that was lax and imprecise (Skrzypińska, 2004, p. 13).

K. Skrzypińska, as well as the authors she indicates, "made an attempt to verify the solid empirical (confirmed) experience and manifestation of spirituality" (Skrzypińska, 2004, p. 13). Her definition, however, does not distinguish between common, superficial spirituality (spirituality) and deep spirituality, which includes experiences and manifestations of a higher order and is referred to as spiritualism. She also mixes their meanings within the category of spirituality ${ }^{2}$. Incidentally, in specialist dictionaries, glossaries, and encyclopedias, there is no separate, alphabetically listed category for deep spirituality, which I define in the text as spiritualism.

\footnotetext{
${ }^{1}$ In the first translations of the New Testament, the expression spirituals meant a person led by or who had been under the influence of the Holy Spirit. It was only in the twelfth century that the definition of spirituality began to refer to a separate psychological function (Skrzypińska, 2004, p. 14).

${ }^{2}$ See: D.A. MacDonald's statement regarding the concept of spirituality (Skrzypińska, 2004, p. 13).
} 
The varied understanding of the concept of spirituality is related from one side to superficial and common experiences ascribed to the notion of spirituality. An example in this respect is the definition of the key word "spirit-matter", included in the Lexicon of Classical Philosophy by Jacek Judycki (1997, pp. 129-131). The expression "spirituality" in this definition describes a feature that is characteristic for humankind. This "spirituality" is introduced "as an immaterial progression of the thinking process" (Judycki, 1997, pp. 125). This process is referred to as the human spirit, a spiritual being, as opposed to a material being. However, this concept was characterized in a manner that is clearly superficial and follows the logic of common reasoning. It is non-scholarly and non-philosophical, even though the lexicon suggests that its content is solely of philosophical nature.

On the other hand, there is also a deepened understanding of spirituality, deep spirituality - when it is, for example, related to, as a derivative and supportive expression, and at the same time a complementary definition within the spiritual category in the perspectives of Plato and Aristotle. It seems that Judycki confirms this by stating that:

"according to Aristotle, the spirit (NUS) is the highest part of the soul, an immaterial principle of thinking which is characterized by an indivisible unity, imperishable, divine, a shaped form of the invigorated body" (Judycki, 1997, p. 129).

For a more complete in-depth form of spirituality, i.e., deep spirituality, the category of spiritualism mentioned above and below would render Judycki a service.

Generally speaking, spiritualism (not to be confused with spiritism) is (in terms of its languagesource) a philosophical term. From the spectrum of ontology and axiology, it assumes that spiritual reality, self-awareness, consciousness, or even psychological experiences are a part of human nature. They are elements of a higher order and take precedence over matter. They constitute, in an anthropological context, the existence of a higher order than the body and, at the same time, a higher order than the spiritual experience of superficial and common values.

On the basis of philosophical anthropology, the ideas of spirituality and spiritualism "oppose", the materialistic concept of humankind. The extreme form of spiritualism assumes that humans are only or mostly spirit; their relationship to the body may be attributive or only apparent. This point of view is typical when referring to Orphic anthropology (Krokiewicz, 2000, pp. 7-78; Kosiewicz, 2007, pp. 18-37) from the viewpoint of Pythagoreans and Neo-Pythagoreans, Plato and Neo-Platonists, Origen and Aurelius Augustinus, and some Augustinians.

However, spirituality of a moderate (similar to superficial) nature and superficial spirituality assume the existence of two substances: spiritual and material. Qualities of the former are reason and freedom. The latter is characterized by expansion and movement. The moderate version assumes that an individual being consists of two interrelated elements: the body and the soul. The qualities, projections, and psychological ideas related to this concept are connected, according to this point of view, with the manifestation of intellectual experience. Acts of freedom and other psychological experiences are a result of the soul's activity, i.e., they cannot be reduced to a physiological phenomenon (Kosiewicz, 2000, p. 137).

Also in the ideas of Simon Robinson, a British psychologist connected with the University of York and a researcher of spirituality, one can observe lack of distinction between spirituality and spiritualism. Therefore, these phenomena seem to interlace the qualities characteristic of superficial spirituality and of deep spirituality. Robinson focuses on only one concept of spirituality, namely human spirituality. He claims, among other things, that this term relates to the practice, experience, and faith that are necessary in psychological and physical relationships with other entities.

Human spirituality is, in his opinion, a simplified and superficial knowledge of people, an awareness that is focused on individual existence and a reflective dialogue with others. It requires closeness and, at the same time, distance to others within interpersonal relations, so that one can maintain the autonomy of his or her, as well as others' identity. It is characterized by recognition of others' subjectivity, belief in one's 
own abilities, and trust in the changes that the future will bring. It is determined by the acceptance of objectives that we set.

Human spirituality is directed, in the opinion of Robinson, at oneself (person centered) and other parties (other centered). It develops in realistic (realistic) situations through dialogue (dialogic) and practice (practical) thanks to dynamic (dynamic) interaction comprising risk (risk related), for example, when driving a car. It is of transdisciplinary (transdisciplinary), holistic (holistic) and at the same time inclusive (inclusive) nature. It deems, for example, institutional religions as special manifestations of spirituality (Robinson, 2007a, pp. 35-37). All of these concepts correspond to the exposure of qualities that are characteristic for superficial spirituality, described by Robinson as spirituality.

On the other hand, Robinson expands on the topic by adding that spirituality does not restrain itself to religions that exist in a formal sense; he indicates that spirituality is also formed on the basis of confessional communities and social institutions. The author therefore assumes, as mentioned above, the existence of diverse forms of common spirituality (spirituality). He also observes that this type of spirituality has currently become popular to a substantial extent, raising interest in spirituality in relation to well being, health, and personal growth. It has become the subject of studies of various organizations and social sciences, as well as the basis for individual experiments (Robinson, 2007b, pp. 20). In this context, we already speak of the phenomenon of deep spirituality, and thus of the qualities related to the concept of spiritualism.

The views of Skrzypińska and Judycki (implicitly intertwining) the terms spirituality and spiritualism are only partially similar to my understanding of the concept of spiritualism, as their reflections on spirituality primarily focus on spiritual experiences that have superficial or common overtones.

However, Robinson's concept of human spirituality is closely related, in my opinion, to the concept (presented above) of spiritualism, even though the reflections I present refer to the issues only in the scope of spirituality.

Like other Polish- and English-speaking philosophers, Skrzypińska, Judycki, and Robinson do not differentiate between the concepts of spirituality and spiritualism. Therefore, they do not use the concept of spiritualism when describing human psychological experiences. They apply only one term - spirituality as a basis for reference for what I differentiate to superficial spirituality (spirituality) and deep spirituality (spiritualism).

This also becomes apparent when Robinson argues, for example, that the psychological experiences attributed to spirituality can be considered only from the point of view of the assumptions and axiology underlying religion, ethics, or psychology (Robinson, 2007a, pp. 34-37). The narrowed examination of all spirituality aspects to the scope relevant only to spirituality is a reductive approach. Robinson forgets (or overlooks) the important role of philosophy and sociology in the given subject matter.

I would like to emphasize that also for this reason I go in my deliberation on competitive sports (high performance, professional, spectator, and Olympic) beyond the theoretic perspective suggested by Simon Robinson.

1. I not only include the category of spirituality, but also the concept of spiritualism;

2. The extension of theoretical context is also based on the relationship between competitive (etc.) sports and spirituality and spiritualism, which I examine from philosophical, ethical, sociological, and religious perspectives;

3. I discuss the categories of spirituality and spiritualism, which take into account religious values (and their association with sports), from the angle of religious philosophy, an independent, nonconfessional philosophy that is not implicated in any religious or para-religious ideological issues. 
In the next part of the text, I mainly introduce reflections regarding the relationship between superficial spirituality and deep spirituality (spirituality and spiritualism) against ancient and modern sports, specifically the Olympic Games. In the final part, I present my critical approach towards the overrated views on the influence of normative ethics on sports, including the importance, role, and influential potential of normative ethics. These indicate that:

1. Normative ethics is an essential ontological medium of sports;

2. Normative ethics is also the most valuable axiological substrate and binder of sports;

3. Sports activities should be treated, above all, as a specific moral mission, dedicated to promoting some intuitively understood, universal - and thus undeniable form of normative ethics. This is obligatory for all, without exception, both in the present and in the future;

4. This mission includes deep spiritual qualities which I presume are only distinctive of the concept of spiritualism.

The views regarding this mission are for the most part inspired by the works of Pierre de Coubertin and the assumptions of Catholic personalism. Its axiological, and more specifically - ethical message assumes, as I have implicitly suggested above, the form of Kant's categorical imperative. It implies the exceptional need to broaden, through athletes and people connected with other sports, some kind of a subjective understanding, and at the same time a universal good, intuitively accepted and praised among all people, especially among competitors and others directly connected to sports, as well as among spectators of events in or outside the sports arena. This good could be defined or understood as a vaguely identified good in Plato's teachings. However, as in Kant's categorical imperative, it does not have a universal dimension (see J. Kosiewicz, 2014a, pp. 12-13; Kosiewicz, 2015, pp. 77-78) ${ }^{3}$. It should be noted that

${ }^{3}$ Pluralism, relativist ethics, ethical panthareism, and potential moral chaos and anarchism are the objects which moral philosophy attempts to overcome through rigorous solutions, not allowing for other moral points of view. This refers to philosophy of a religious nature (which uses, for example, the ethics of Catholic personalism - a system which is only partially, if at all, related to theology), as well as non-confessional philosophy, referring for example to the ethical principles included in Krytyka praktycznego rozumu /Critique of Practical Reason/ (Kant, 1984a) and Uzasadnienie metafizyki moralności /Groundwork for the Metaphysics of Morals/ (Kant, 1984b).

A reference (not very fortunate) is made in this case to Immanuel Kant's categorical imperative as an example of an infallible foundation, which would eliminate the formal and axiological ambiguity of normative ethics. The given imperative is in the following wording: "Act so that you use humanity as much in your own person as in the person of every other, always at the same time as end and never merely as means" (Kant, 2012, pp. 46-47). Meanwhile, Kant himself surprisingly introduces a huge breach in this principle, which very strongly undermines universality and obligation - he relativizes it and suspends, the ruthless tone towards criminals who breach criminal, administrative, and civil law. He states in the footnotes of the second comment related to this imperative that an offender can turn to law enforcement officials and ask them not to do as they would not be done by and not to treat them as a means to achieve the aims accepted by them (in their profession) and the society. He also writes that "the criminal would argue on this ground against the judge who punishes him" (Kant, 2012, p. 47). Kant assumes that if a criminal (or any other offender) does not treat others in an autotelic manner, as a goal in itself, then he or she becomes a victim of his or her own wrongdoings. If a criminal treats his or her victim as a means to fulfill their own needs, Kant says that they suspend the effect of the categorical imperative for themselves.

Therefore he establishes a clear, incontestable primacy of law over normative ethics, in a sense that the character of normative ethics is necessary, and therefore essential and universally binding.

From this point of view, a criminal should always be treated as a mean to achieving social goals, outlined by law, but never as a means in itself. Metaphysical explanations of morality and the categorical imperative related to it, derived from God and pure intelligence, carry less weight and meaning than the law that was established by man and which has different forms in different societies.

If the categorical imperative cannot be rigorously applied in ethical objectives, then we are in fact dealing with moral relativism. It is not dependent on only one specific law, whether criminal, civil, or administrative, as such dependence is not possible, but rather on many (including some highly) undemocratic legal codes, that differ from each other to a significant degree, which was especially true in the time of Kant. The categorical imperative can often comprise a given moral norm, while at other times it cannot; this depends on the prevailing moral law in a given country. Some kind of moral norm (e.g., the prohibition of incest) could be regarded as common and necessarily binding and any breach of this prohibition should be penalized by criminal law. At another time, in a different place, incest may be accepted from both a moral and legal point of view. In this case, the authorities and the laws they enforce are the deciding factor (Kosiewicz, 2000, p. 55), and moral demand, the categorical imperative, is secondary to the law 
I am entirely omitting the relationship between psychology and spirituality in my investigations related to sports, as I do not have the appropriate competence in the field of psychology, such as Simon Robinson has.

With regard to numerous definitions of spirituality, and in order to recapitulate the above investigations, one can assume that deep spirituality relates to psychological experiences, feelings, and thoughts that are not so much of a cognitive nature, but more of an emotional and evaluative one. Therefore, the activity of autotelic properties emerges, which comprises aesthetical experiences, or other emotional motivations and subordinates our own private individual needs (and not the needs, objectives, and expectations of others) to our intuitively sensed collective beauty and sense of justice.

This activity also relates to the realization of views and ideas connected with sublime love, honesty, and various understandings of public good, as well as ideas with humanistic overtones. It is assumed that the attitude of complete dedication, connected with the artistry, aesthetics, responsibility, and morality of the Romantic period, is instilled with emotionality and spirituality of the highest order. Subsequently, it is assumed that autotelic, ideological, and humanistic experiences of a secular and religious overtone also refer to the realization of various forms of high culture, art, and literature. They correspond to social, national, group, family, or patriotic needs (and their realization) and are also abundant in deep spirituality.

\section{Brazilian football: religion or a superficial spiritual phenomenon?}

Superficial spirituality (spirituality in the common sense) shows a tendency to bring to life only common values, which are situated in generally accepted, internalized, and approved of hierarchy of values. An example of such approach could be even a fully emotional relationship with football that is apparent in Brazil, and which is sometimes mistakenly perceived as having qualities of some secular form of religion.

It is worth adding to the above statement that religion is differentiated by four main components: cult (referring to forms of worship), doctrine (the teachings), a sacral organization (e.g., Church, understood

and depends on points of view that oppose each other. Suspension of the imperative depends on various and diverse legal arrangements and leads not only to ethical relativism, but also to moral chaos. What is moral in one country can be considered a crime in another or an exemplary virtue in yet another. For example, having one wife in the Catholic faith is a legal norm as well as an ethical categorical imperative. However, polygamy is acceptable in Islam both legally and morally, but it cannot and will not become a categorical imperative, as not everyone is able to maintain many wives.

This reveals another dependency on law. The categorical imperative in the narrower sense can only include norms and moral behaviors that are not prohibited by the law in a given country. It is common and necessary in a restricted sense (such as doping among sportsmen in the Democratic German Republic and the Soviet Union). The categorical imperative in the wider sense - according to Kant - refers to ethical norms that do not conflict with legal regulations of all the then states, both democratic and non-democratic ones. That fragment shows that he understands and interprets them in the spirit of positivism.

This type of suspension is fraught with consequences that could lead to neutralization and the total abandonment of the use of that imperative because crime can be relativized and ambiguously understood and have multiple, different characters and different connotations depending on the culture, civilization, needs, situations, and social circumstances. From one perspective, murder could be treated as a violation of the categorical imperative, and from another as a necessary act that brings the desired and expected effects by employers of a totalitarian regime. Thus, one can conclude that anyone who suspends the imperative against another also suspends it for themselves and should be treated instrumentally and be punished.

Treating others as a means to a given goal does not have to be punishable at all. This phenomenon is abundant in almost every manufacturing process and in professional, Olympic, and spectator sports.

Other "justifications" of the imperative indicated by Kant in Grundlegung zur Metaphysik der Siten (2004) derived from the belief of the existence of a noumenal world, which is inadequate because it is based on the need to demonstrate the existence of higher education, that is, pure intelligence (including the Christian God). It is impossible from a scientific (including empirical) or philosophical standpoint.

Saturation of praxeological rules, including the law and regulations of competitive sports with moral norms would be a substantive and formal mistreatment. Normative ethics is completely external with regards to formal regulations. Normative ethics applies instrumental, utilitarian, pragmatic, and praxeological (but not autotelic) criteria that regard effectiveness. Moral solutions are external interpretations in relation to what is autonomous. Moral interpretations can vary depending on their foundation, i.e., they can be subjective and discretionary, like a review of a performance prepared by a theater critic. 
as a social institution), and normative ethics with a soteriological impact that defines attitudes and behaviors conducive to the targeted salvation.

For example, in Brazilian football - as in football of other countries - aspirations of the competitors and the expectations of the supporters are not concentrated on the success and good of all teams, but on the victory of a specific team, at the cost of one or many others. This is mainly determined by competitors' behaviors, which have praxeological and pragmatic qualities and are focused on practical effectiveness rather than on spiritual and religious experiences and ways of conduct.

Supporting sports is not a form of participating in a cult; it is a way of showing friendly interest and kindness to the competitors and the people involved in the competition - those who cheer players on and encourage them to win the game, which is the objective of a sport, and not of religion (even in the in the more general sense).

As in other modern competitive sports, there has never been a specific doctrine in Brazilian football that would teach about sports and refer to the assumptions or religious qualities of the sport, either in a narrow and broad sense. Nowadays, education in sports is only supplementary, and is often a partial form of cultural pedagogy that communicates knowledge with regard to various social relations and values. The objective is not, in the opinion of the mentioned pedagogic form, to breed or bring up specific "priests", spiritual guides, or ideologists, whose primary objective is indoctrination and glorification of values and manifestations of sports.

Active participation in professional sports is primarily determined by general and specialized physical fitness, technical and tactical skills, as well as intensive training characteristic to specific sports disciplines. It is not shaped by widely understood religious inclinations. At the core of every discipline are rules and game regulations, which are of a praxeological nature and are devoid of assumptions or postulates from the field of normative ethics. They streamline aspirations toward a variously conceived sporting success, which is either measurable or discretionary.

This refers to victories in tournaments or placing according to the team's expectations in the ranking, as well as other forms of satisfaction including financial gain or social, political, ethnical, or professional recognition.

\section{Spirituality, spiritualism, and the Olympic Games}

Brazilian football and other modern competitive sports are above all else manifestations of superficial and popular mass culture in schematic and simplified forms. Their emotional impact can be stimulated and enhanced by social, economic, and political circumstances (incidentally, no interreligious rivalry or exclusivism is observed here).

They create values of an epidermal nature located outside of the high culture.

Neither spirituality nor spiritualism makes the primary objective, or the expected value here. Rather, they are additional or unnecessary qualities. The competitor concentrates primarily on the main objective of the intended and ongoing rivalry. The emotional thrill before, during, and after the tournament that permeates the athletes and the audience is a sign of psychological and emotional tension that accompanies the struggle in the arena. In some situations we deal, at best, with a superficial spirituality (spirituality) ${ }^{4}$.

\footnotetext{
${ }^{4}$ In truth, the text focuses on the relationship between competitive sports (high performance, professional, spectator, and Olympic) that are conducted all over the world and the concepts of spirituality and spiritualism. However, it is still worth briefly paying attention to the relationship between these concepts and sports in general (physical recreation, tourist forms of physical recreation, physical education, school sports, games, sports for the disabled, or other behavioral-exercise movements of a healthy nature).

On one hand, it is assumed that this type of activity is often full of spiritual experiences of a superficial nature (spirituality); on the other hand, this points to the difficulties that are associated with the notion of deep spirituality (spiritualism). Spiritualism is not necessarily emphasized by inspiring those who are currently active in the field
} 
It sometimes manifests itself in various sporting ceremonies. They are often given apparently "deeper" significance by means of serious but very rudimentary musical arrangements (for example, in the form of the Olympic Hymn by Krzysztof Penderecki and other occasional works of classical music) associated with high art. We are then faced with the proverbial window dressing, with artistic ornamentation derived from another area of activity (Kosiewicz, 2015, pp. 11-36). Such performances do not influence the genus proximum in any way; they do not subordinate competitive sports to the values of philharmonic, operatic, or other stage forms of music and the possible emotions or manifestations of deep spirituality connected with them. They also have no influence on the generic essence of sport - neither in its universal meaning (if possible to define), nor in its particular variants, characteristic for specific sport disciplines and the competitive rules related to them (see Kosiewicz, 2014, pp. 64-73).

In contrast, the Hellenic Olympic Games were a highly sublime form of athletic activity. They constituted one of the many forms of worship of the chosen gods belonging to the Olympic Pantheon. Both in sports and theatre, as well as in various forms of art (reflecting important cultural values, characteristic of the Greek paideia; Jaeger, 1964), Agon was mainly a manifestation of adherence to the binding axiological rules of the then religion. The athletes and audience courted the favor of the chosen gods ensuring success in world life, possible salvation, and the achievement of eternal happiness in the eschatological dimension (in the afterlife). The agons were indeed a manifestation of deep spiritualism (spiritualism), based on soteriological ethics.

At that time, fitness and exercise, sporting perfectionism, and high specialization had both autotelic and instrumental values. In a given situation, they preceded the far-reaching anthropological-cultural and spiritual-bodily cohesion that disappeared along with the collapse of the ancient Olympic Greek Agon.

The abovementioned anthropological-cultural and spiritual-bodily unity applied to all of the Olympic Games, including the Athens Biennale. The Athens Olympics differed from the rest of the games in that none of the spiritual-bodily components of the Olympic unity were mere athletic activities. The first of these components related to artistic-aesthetic emotions. The second component, reaching beyond art itself, was wine, the gift of Dionysus, which brought one closer to God. Alcoholic intoxication strengthened in a peculiar, sacro-emotional manner experiences of aesthetic-theatrical nature (including various forms of drama); it led to a profound mystical communion with God, with Dionysus. It was that special closeness

of general sports; spiritualism is not the aftermath or the result of conduct with respect to these forms of sports (Kosiewicz, 2014b, p. 77).

Despite this, however, it states the existence of significant exceptions relating to experiences full of values in the field of spiritualism that are associated with certain recreational forms of tourism, sometimes directly in competitive sports. Therefore, during mountain hikes and mountaineering, there may be a manifestation of deep spirituality (spiritualism) that is significant for the hiker or climber's experience relating to qualities that are non-, para-, and strictly religious. This applies to the anesthetization of nature, assigning to it, for example, architectural qualities and shapes typical of the Gothic style, artistic qualities, cultural initiation, and extroverted and introverted deepening spiritual experiences, as referred to in the works of Mariusz Zaruski (Krawczyk, 1970; Kosiewicz, 2004, pp. 396-406; Gołaszewska, 1994, pp. 234-250; Zaruski, 1958a; Zaruski, 1958b; Zaruski, 1958c).

It is also associated with a sacralization of nature that is of a pantheistic or panentheistic quality. In the first case, a traveler or tourist mountain climber feels that the deity - for example, one that is specified or unspecified and is variously understood as the spirit of the mountains - makes them a part of nature. In the second case, they do not lose their autonomy because it exists both in and outside of nature. This also applies to mountain animation, as one would assign them the function of an observer of human behavior.

Evidence of deep spirituality manifests itself in the attribution of charm and other qualities of temples to the mountains; churches, cathedrals, basilicas, synagogues, Orthodox churches, and shrines also have the feeling of the supernatural. However, non-religious qualities of nature that enable one to experience unity with a divine being suggest the emanation of eternity, immutability, and dangerous and untamed power; they arouse fear, trembling, and anxiety before the unknown, like Soren Kierkegaard and Rudolf Otto's conception of God (Kosiewicz, 2004, p. 300; Otto, 1958; Kierkegaard, 2006).

Spiritualism also refers to a variety of Indian yoga forms, which are a set of physical exercises in the field of recreational movement, whose basis indefinitely stems from assumptions closely connected with deep spirituality. This method of widespread physical activity is more (spiritualism) or less (spirituality) a sublime form of physical culture in Western Europe. 
which confirmed the relevance and meaning of the Olympic event. Both the ceremonial and non-ceremonial consumption of wine as well as the active (artists) or passive (audience) participation in the several-day-long theatrical Olympics were forms of a cultural manifestation and spiritual sublimation, and the affirmation of the Dionysus cult.

The fascination with that form of sacrum is also reflected in the fact that no further than a 20-minute walk from the ancient Olympia (once numbering only a few hundred inhabitants) are slopes with a wellpreserved ancient stone amphitheater that could hold five thousand spectators. Followers of Dionysus and lovers of the theater from the major part of Hellas would come for a few days to be spectators at the Olympics.

It is worth mentioning that Dionysus was supposed to be the son of Zeus and according to mythological history, his successor, as well as a more powerful ruler than his father. Dionysus was honored with special games, harmoniously joined in the mainstream of that form of activity, since the ancient theater, both in the forms of tragedy and comedy, had emerged from Dionysia (Bacchanalia) $)^{5}$ and the Bacchantes cult ${ }^{6}$ in particular. Rivals entering the competition presented a tetralogy consisting of three

${ }^{5}$ Dionysus originated, among others, from the original rites of the Bacchantes (in the tragedy of Euripides' Bacchae).
This ceremony, which was typical for the group, is called Bacchanalia; it was full of mystical orgiastic frenzy and had
music, instrumentalization, choreography, dance, and song. It occurred at night in remote lands and in mountainous
woods. The ceremony gradually transformed into two different forms in secret mysterious religions and Dionysian
carnival parades that extended onto the streets, in between public squares, on streets and areas surrounding the city,
around the city, and between cities. An improvised and rhapsodic dithyramb came from this, as well as ceremonial
chants and the modification of Greek tragedies. Bacchantes are also a source of komos, from those frivolous
masquerades that ended in a phallic song, comedies of a satirical nature which were erotic. The name comes from
satires that took part in them who had a large leather red member or fallos - the main idol of the Bacchantes - protruding satires that took part in them who h
from under their short garments.

The artistic presentation took place in an architecturally structured outdoor space known as the ancient Greek theater (Kosiewicz, 2013).

${ }^{6}$ Dionysus astonished - more than other Greek gods - with greatness and freshness of his epiphanies, as well as by variety of his transformations. He was always on the go. He reached all countries, peoples and religious milieus. He united with different, even opposite, deities: for example with Demeter or Apollo. He was surely the only Greek god who - revealing himself in various forms - shocked and simultaneously attracted peasants, intellectuals, politicians, amateurs of contemplation and of orgies, ascetics. His presence announced enthousiasmos or mania, ecstasy, eroticism and common fertility. It was possible to get close to him, and even fully unite with him, liberating oneself from seemingly impassable limits of the human condition (Eliade, 1988, 1, p. 259).

Theories concerning the origin and transformations of Dionysus and his cult are very different and tangled. None of them are fully certain or explained. For example, the god's origin is not synonymous with the origin of his cult at all. I have tried - in my considerations of the subject of Bacchic frenzy - to omit the abovementioned issues, in spite of the fact that they penetrate the main current of the presented discourse. I did it - similarly as in other cases - to maintain clarity of the main argument.

E. Rodhe thinks that the cult of Dionysus thoroughly changed character of the Greek religion, and that it contributed to breaking the barrier separating the human world from the gods' world, to passing the border separating the human soul from the sublime divinity inaccessible for the human being. He presented him and his cult as a power making it possible to experience periodical and crazy mystical delight, which promised the human being - in a further and the final perspective - uniting oneself with Dionysus in eternal and holy bliss. He pointed also to Thracians' ecstatic drinking and using wine by them as an intoxitating means during wars (Lippki, 2003, p. 78; Kerenyi, 1997; Rhode, 1901, p. 332).

The aim of Bacchic initiations was to arouse the feeling of a union with transcendence and to experience everlastingness and indestructibleness in an inspired unity with the deity (Wargacki, 2003, p. 137). Thanks to crazy passion, it was possible to experience illumination, to come close - in an intuitive and direct way - to resources of divine knowledge, to that what usually is accessible only for Dionysus (Godwin, 1983, p. 133). Ecstasy, connected with that passion, led not only to transgression of the human condition with its determinants and limits, but also - as M. Eliade and, after him, K. Banek maintain - to achievement of liberation and freedom which are usually inaccessible for human beings. It made people ignore and pass over all prohibitions and orders, conventions regulating social life, which were a nuisance especially for women. That freedom from them facilitated women's mass participation in the Dionysian movement (Eliade, 1988, p. 254; Banek, 2003a, p. 30).

It is even emphasized that the Dionysian world (with its frenzied, orgiastic rituals) was dominated first of all by women. It is commonly maintained that, similarly as there is no Dionysus without wine, there is no his cult without women. Admittedly, there were attempts to increase participation of men, for example in the second half of the $6^{\text {th }}$ 
century B.C., but - in spite of that - those holy rituals remained dominated by female bacchantes, although superior roles started to be played by male bacchantes.

It comes from myths of the Mycenean Age that Thyia was the first who made an offering to Dionysus and initiated ritual dances worshipping him. Later women who during Dionysians mysteries were seized with Bacchic frenzy were called the Thyiades. They abandoned their hitherto occupations and rushed to the mountains to devote themselves to frenzied orgies, similarly as other women from Old Greek myths (Banek, 2003a, p. 21-22). In "Bacchae" by Euripides the chorus orders the maenads: "crown your heads with ivy,/ blossom, blossom with green/ milax of beautiful fruit/ be mad, be mad with Bacchic frenzy/ with oak or fir branches/ dressed in blotchy nebrises!/ Edge them with white fleece/ and proudly raise/ audacious narthexes. Again the whole country is dancing,/ when Bromios leads circles/ to the mountains, to the mountains where there is waiting/ a crowd of women/ carried away from spinning wheels/ driven by Dionysus" (Eurypides, 2007, pp. 23-24).

In proper moments they discharged original Bacchic rites (Sokołowski, 1911, p. 19), they performed the holiest and the most mysterious part of the cult (among others in the temple in Marshes; that is, in en Limnais, Kerenyi, 1997 , p. 246). They ministered, in deep secret, sacrificial services (for example in Dionysus' temple in Brisaei, at the foot of the Taygetus Mountains. They identified with him and played his role. They worshipped the god by frenzied dancing from dusk till dawn, roused by holy inspiration. Later they participated also in enthousiasmos - that is, in a ceremony full of adoration and mystical rapture. They went in dancing processions along the holy road from Athens to Thebe.

During the original secret rituals-mysteries, taking place in backwoods, far from towns, the Lydian maenads wore "kid skins, ivy crowns on their heads; decorated with garlands of snakes, they carried and breast-fed kids and wolf cubs" (Eliade, 1988, 1, p. 254). That information is confirmed by Euripides, who writes among others that they wore "fawn skins, with snakes in their hair, with garlands of ivy and oak leaves, with thyrsos in their hands" (Eurupides, 2007, 3, p. 22). He points also out that Zeus, having given birth (from his thigh) to Dionysus - "a god of bull's head" "decorated him with a wreath of snakes. Hence animal feeders, the maenads, weave snakes in their plaits" (Eurypides, 2007, 3, p. 23). They drank also wine and, intoxicated with it, they ran in forests and mountains, without limits and selfcontrol, making themselves similar both to Dionysus Omadios and Omnestes (devouring raw meat; a phenomenon called omophagia) and to wild beasts. They tore to pieces (sparagmos) an offering of an animal, they tore apart its shreds (especially of a young deer) from dancing maenads hands. They drank its blood and bit raw meant.

It was a reference to Dionysus Zagreus' - in this case, Baby Dionysus' - mythical, martyr's, sacrificial death at the hands of Titans sent by Hera, which simultaneously augured his revival (Eliade, 1988, 1, pp. 256-259; Kosiewicz 1998b, pp. 19, 91-93). Torn apart and devoured animals were Dionysus' epiphanies or they reflected his incarnations, and the abovementioned intimacy with snakes and young wild animals was possible thanks to mystical ecstasy inspired by identification with the god (Eliade, 1988, 1, p. 254). That sacral - and simultaneously archaic behaviour - constituted also a specific testimony to and a confirmation of the need to come back to "behaviours rejected thousands years before; similarly violent frenzy was a visible proof of a contact with vital and cosmic forces, and it could be only called a possession by a god. It should have been expected that that possession would finally turn out to be "frenzy", mania. Dionysus himself experienced "frenzy"; hence a bacchante only shared the god's experiences and torments; after all, it was the most certain method of uniting with him (Eliade, 1988, 1, pp. 254-255).

The abovementioned imitation of archaic cultural heritage constituted the highest stage of Dionysian mystical ecstasy. Later those original forms of cult were "domesticated", "nevertheless, moderated and institutionalized, they fit into regulated, cultic order of the community" (Łanowski, 2007, p. 12). They transformed into orgiastic holidays of carnival character, which took place in towns or on holy roads leading from one village to another. They took on, among others, forms of marches and processions.

Bacchic orgies were accompanied by dissolution and madness, they blossomed in frenzied manifestations of worship. They caused unparalleled excitement, daze, trance, exaltation and ecstasy, feeling of limitless happiness and joy.

Both women and men who participated in ceremonies worshipping Dionysus achieved altered states of consciousness, a phenomenon characteristic for various mystical currents. Then they were sure that they are overwhelmed by the god, they felt his direct influence. Wine brought by men to temples was drunk, people gorged themselves on it during processions. It caused a state of unusual excitement, of an rapture akin to mystical bliss, it facilitated its full coming into being (Srebrny, 1984, p. 68). People were dancing while drinking it and singing to worship Dionysus. With the course of time those orgies became so common that during them, e.g. in Tarentum, all the town was full of drunken inhabitants (it is pointed out by Megillos in the $1^{\text {st }}$ Book of Plato's "Laws", who says that „In Tarentum, our colony, during the Dionysia I saw the whole town drunken” (Plato, 1997, p. 351). Participants of the Dionysia, more or less dazed by wine, came to the theatre for a tetralogical competition dedicated to Dionysus, whereas in Athens drunken men drove carriages in ecstatic rapture (Plato, 1957, 357; Banek, 2003b, p. 60). The autotelic aim was not an orgy, it was only a means, a peculiar instrument determining coming into being of ecstasy, which made it possible for the soul to transgress borderlines of the body (Hoffmann, 2003a, p. 90).

In the case of Bacchanalia we indubitably have to do with madness which comes from "divinely inspired release from normally accepted behaviour" (Plato, Phadreus, 265) and that what is divine is has, after all, beauty, wisdom, goodness and everything of that sort" (Plato, Phadreus, 246D).

On the basis of the abovementioned considerations, we can assume that Dionysian ceremonies inspired a specific form of ecstatic frenzy, an inspiration characteristic for ancient Greek culture. Mystical ecstasy stimulated, generally speaking, for transcendentally determined creative activity in the field of creation of innovative ritual elements, such 
as among others original music compositions and arrangements, vocal expositions in the form of singing poetry, dancing figures, dithyrambs.

Influence of the discussed ceremonies on musical frenzy was extremely significant. R. Gansiniec points out that Dionysus was not only the god of wine, but also the god of music of Phrygian provenance, where the dominant role was played by the flute and the tambourine. They had eliminated the Hellenic phorminx or lyra. The factor initiating collective character of mysteries-related ecstasy was rhythmic music of specific sound and rhythm. "It is universally found that just the tambourine liberated germinating demonism and, with its rhythmic sound, it enslaved women predisposed for blatant madness". The flute and the tambourine caused and precipitated ecstasy, "and there were Dionysian instruments, which did not sound daily, but only on God's holiday" (Gansiniec, 1934, pp. 279-294; after: Hofmann, 2003b, pp. 51-52).

The main aim of the dance was striving for unity with sacrum, for transgressing everyday and common life (that is, profanum), for reaching the holy destination - a temporary subject's annihilation - for inspired self-saturation with divinity. The dance was an exposition of sacral-aesthetic frenzy, which overwhelmed both the dancer and the dancing group, and whose supernatural content was accessible only for the initiated. Its expressivity was strengthened by esoteric gestures and exaggerated countenance, as well as by numerous inspired cries and initiating statements, which emphasized ecstatic character of the trip beyond reality, self-liberation from bonds of the earthly existence.

Dancing figures revealed "transcendent presence" of divinity in their whirling movement. Their divinization, saturation with divinity, took place - they were transferred close to the deity or even panentheised. Dance seemed to be the most efficient in that respect, because - according to their feeling - their greatest got appeared there during their girlish dances. The distance between him and the dancers disappeared. They all united with Dionysus in the holy dance (Benisz, 2001, p. 371), because in that case "a figure of the dance unite gods and people on the same level of existence" (Kerenyi, 1997, p. 25). It means that the god - according to their opinions and experiences - united with them, but he did not lose his versatile autonomy.

Dance was also a manifestation of creative activity. There took place a combination of a mystical experience with creativity, which at the beginning was quasi-artistic and then artistic in the strict sense of the word, similarly as in the cases of music, singing (and poetry), chorea and then Old Greek theatre. Eliade proclaims that "The dithyramb, the tragedy, the satiric play are, to a smaller or a greater degree, Dionysian creations. It is exciting to watch the process of the transformation of the collective rhythm (dithyrambos) - causing violent ecstasy into the spectacle and, finally, into a literary genre. If some public rituals became spectacles and Dionysus was made the god of theatre, other secret and initiating rituals developed into mysteries" (Eliade, 1988, p. 259).

F. Nietzsche emphasises that during those rites their participant undergoes a significant transformation. He becomes "both an artist of dream and an artist of rapture (...) tipsy with Dionysus and in mystic isolation" (Nietzsche, 1994, p. 39). He points out that "the man, singing and dancing, shows himself as a member of a higher community he has stopped walking and talking, and soon he will fly up, dancing, in the air. His gestures reflect enchantment (...) there is a note of something supernatural in them: he feels a god and he strides so delighted and sublime as he saw in gods in his dream. The man has stopped to be an artist, he has become an artwork (...) he reveals himself in a thrill of rapture" (Nietzsche, 1994, pp. 37-38).

The abovementioned sacral-ecstatic behaviours were different from prophetic and purifying inspirations coming from Apollo. There appeared, however, a form of trance called a Pythian trance, which, admittedly, did not include hysteria and possession typical for Dionysus' cult in the primal period, but which, nevertheless, was described by Plato as a frenzy comparable to poetic inspiration coming from Muses and Eros' love impulses (Eliade, 1988, 1, p. 191; Plato, Phaedrus, 265 B). They corresponded to bacchantes' sexual passions, and especially to experiences characteristic for orgiastic processions.

What was emphasized was the need of fulfilment of erotic expectations of persons taking part in them, such as e.g. "female participants of the Dionysia playing around with satyrs" (Gansiniec, 1934, pp. 279-294; after: Hofmann, 2003 b, pp. 51-52). It is proved by an image of Dionysus, with the maenads and naked ityphallic satyrs, which is often found on coins from Lette at the Thracian coast (Head, 1911, pp. 198-265; after Banek, 2003a, p. 23). In processions which worshipped him, satyrs and sileni carried phalluses (Hammond, 1994, p. 218). Dancers in those processions had a great, leather, red male member - phallos - sticking out from their short clothes. Huge wooden phalloses were carried as symbols by participants of processions called phallophoroi (carriers of a phallos). In narrative threads of komos (which was the root the comedy appeared from) there were mentioned processions of satyrs (Ziętek, 2003, p. 102) and the connected frivolous masquerades ended with a phallic song (Nicoll, 1977, p. 11). "The Dionysia in general were accompanied by unrefined pranks and jokes. The ceremonies had character of joyous holidays of wine and fertility, and that is why humour concerning sexual issues not only was not forbidden, but it was obligatory and sanctified. It gained ritual and, what follows, sacral - power" (Ziętek, 2003, p. 100).

The Dionysian procession ended with a person carrying the phallos, which - together with the mask - constituted two idols of the Bacchic myth characteristic for ancient Attica. With the course of time the phallos became an autonomous idol symbolizing Dionysus himself and later it even turned out to be more representative for his divinity and more popular among his worshippers than the idol in the form of the mask. "While the Phallophoria was an 'overt' ceremony, when the Dionysian idol was openly demonstrated, female ceremonies with the liknon, where the idol was placed, maintained some element of mystery and hidden symbolism. Not only the content of the liknon was closely bound with the covering cloth, but the very ceremonies were characterized by the same mysteriousness. As far as we know, the women performed many cultic 
tragedies and a comedy. There were also contests in writing tragedies. Incidentally, Plato (as stated by Diogenes Laertius) also sought to participate in one of them (Diogenes Laertius, 1925, p. 271).

The ancient Greek Olympic Games were, in contrast to the modern Games, a specific combination of carnival and mystical values. They also expressed the joy of living within both Panhellenic and local, cyclic meetings and religious manifestations. In the beginning, the Olympics were accompanied by the sacred rituals performed by priests in the temple located within the ancient theatre. The ceremonies honoring the victors also had a mysterious nature that was manifested in the artistic-religious and athleticreligious struggles and in the high piety of the mystical-athletic and ecstatic-artistic competitions.

activities to worship underground Dionysus. That way they thanked him for the gift of wine and - what is more important for the gift of manhood, which was generously distributed by the god" (Benisz, 2001, p. 400) and continuously present as a shrinking and bulging fullness.

It is certain that an important role in striving for understanding of the Dionysian mysteries, which opened access for secret recesses of the human soul, was played by the abovementioned satyr with the symbol of the phallos, which was omnipresent in the Dionysian cult. Nowadays the notion of the satyr is saturated with banality, while "in antiquity it included a limitless charge of Dionysian power" (Benisz, 2001, p. 62). According to Greeks' conceptions the goat-like satyr "is the man's archetype, an expression of his highest and strongest stimulations: an inspired dreamer, who is delighted by the god's closeness; a compassionate companion, who repeats the god's suffering, a harbinger of wisdom from the deepest depth of nature's womb; a sensual sexual picture of omnipotence of nature (...) he was sublime and divine (...) his look was full of sublime satisfaction (...) here the real man revealed himself, a bearded satyr screaming joyously to his god" (Nietzsche, 1994, p. 67). Continuing that apotheosising statement about the satyr's qualities and significance, Nietzsche concluded in the following way: "the Dionysian Greek desires truth and nature in their greatest power - he sees himself transformed by a spell in a satyr" (Nietzsche, 1994, p. 70).

Assumptions and religious behaviours characteristic for primal and carnival forms of the Dionysia significantly influenced Plato's conception of man, and especially the philosophical interpretation of madness of creative character, which significantly influences development of culture and memorability - that is, immortality. Dionysian frenzy and its Platonic interpretation come from the mysteries inspired by Dionysus Zagreus' (Baby Dionysus') martyrdom. They had: a) ascetic (Orphic) character, b) semi-ascetic character, typical for the bacchantes' orgies far from towns in the mountains, c) hedonistic character - affirming joy and sensual rapture: among others, during religious processions and theatrical religious ceremonies.

They were mediated, first of all, by sensual experiences, because wine - and then participation in collective devouring of bloody meat - constituted in original forms of the Bacchanalia both a precondition and a supplementing condition of the appearing and developing feedback between symbolic participation in tragic Dionysus' dead (including omophagia and sparagmos) and the appearing and deepening mystical ecstasy.

Also in Bacchic dancing processions - full of sensual rapture: symbolism of eroticism and wine - the affirmation of the body and of the din of life constituted an indispensable and necessary condition of experiencing spirituality, as well as of a significantly intensified form of that experience which should be placed within the scope of spiritualism (to be distinguished from spiritism), whose manifestation was a union, ecstasy, mystical bliss.

Very participation in a ritual, a rite, a religious mystery was an experience from the field of spirituality, while an experience of qualities characteristic for spiritualism appeared in the case of significant deepening of the first experience; that is, when a mystical union, co-participation in divinity took place. Its most suggestive proof was frenzy as a passion "rousing to Bacchic inspiration".

Both in assumptions of the bacchantes' original ritual and in the carnival Dionysian procession a condition of experiencing of spiritual values of various depth were bodily experiences. In Plato's views we have to do with a similar situation, and it is not a coincidence. It is proved by his conceptions of man, culture, culture-creative madness and memorability (immortality). An indispensable condition for spiritual arousal, for ecstatic experience of love is sensual inspiration. A superficial amorous contact or a common-sense experience of beauty and good enable only an average or common spiritual experience (realized in the dimension characteristic for spirituality), whereas their intensified experience - taking on a form of madness of, for example, philosophical, religious, musical, dance, vocal, poetic or theatre (like in the case of the Dionysia) character - belong to the area of spiritualism, because frenzy was the most important and the deepest cultural experience, rousing inspiration realizing a creative trip towards memorability, which is difficult to achieve and rarely achieved. That madness liberated from bonds of profanum not only inspirations and a creative act: it constituted also an indispensable criterion of divine - ideal - memorability (immortality of the work and of its creator), an intuitive and metaphysical principle of their perception, their axiological - and simultaneously axiotic - dimension (accessible for receptors).

The mythological foundation of Bacchic frenzy is difficult to reconstruct, because of its rudimentary - that is, fragmentary - writing and archeological documentation, and variety of different, mutually exclusive and equally justified interpretations. Situation of ancient Greeks in that respect was considerably better, because they had access to "the full expression of Dionysus' nature - in myth and picture, in vision and cultural presentation. They did not have - unlike us to find for him an intellectual expression, which will always be imperfect" (Kerenyi, 1997, p. 13). 
Therefore, it should be noted that competition in the field of art did not constitute an external thing or a supplementary action relative to the struggles of sports; it was not an aesthetic or artistic ornament with the purpose to add some value to the struggle of fitness. The musical competitions, performances of songs, dances, recitations of poetry, and theater performances were also a form of worship to the chosen Olympic Gods, Dionysus, Aphrodite, Eros, and the nine Muses. They were evidence of the sacral-religious basis of the athletic-artistic activities. It is religion that assumes a constant periodic and indispensable need to confirm relationships, especially that of a close relationship with the divine transcendence, both during the preparatory period (during the Olympics) and during the Games. The competitive forms of Olympic sports and art inspired and complimented each other. They reinforced the motivation of the artistic and athletic competitors; they were proof of divine inspiration, creative madness, and the struggle for immortality (Kosiewicz, 2014d, pp. 151-162). According to Plato and Socrates in Phaedrus (1993) and Symposium (1984, pp. 18-162), divine sparks, divine inspiration, madness, and craziness are forms of divine encouragement which awakens artistic and religious activity, for example, carnival-mystery sport activities (Kosiewicz, 2014e, pp. 176-211).

However, unlike in the ancient Olympic Games, the artistic competitions were not included at the beginning of the modern Olympic Games; later, they were added as an artificial supplement that derived from a different non-artistic agenda. It did not adhere to the praxeological impact of the modern Olympics ${ }^{7}$. In ancient Greece, sports, and arts were phenomena of the deep confessional spirituality of the divine Olympic provenance.

Nowadays, the combination of art with sports at the Olympics causes legitimate axiological dissonance because the two forms of activity have completely different objectives: they inspire and represent different values, even if a particular piece refers to sports or is present in the setting as an aesthetic context of a sports event. This association is not useful for athletic competitions, though it does have genological qualities. It does turn a sports spectacle into a phenomenon with qualities of high culture that are indigenously saturated with the autonomous and autotelic values of deep spirituality. Truthfully, the modern Olympic Games are connected with many elements from the abovementioned Agon; therefore, they deviated from the message and assumptions of the ancient Greek religion. There is no returning to them.

\footnotetext{
${ }^{7}$ The plan to combine the arts, including literature, with sports did not end well for Coubertin. The main reason for this, as is indicated in the main part of the text, was the lack of correspondence between the basic objectives and the overriding values of sports and arts. Moreover, one can add that at the beginning, the Olympic Games was not treated as a prestigious festivity. Artists did not value sports due to their low social status at that time. In spite of Pierre Coubertin's efforts, they did not manage to organize the first modern Olympic competition for arts and literature in London in 1908 (the fourth Olympic Games). He appeared only in Stockholm in 1912 and did not make it to the Games in London until 1948. The main competition focused on literature and finished in Stockholm as a spectacular failure: only one work was entered in the competition. It was called An Ode to Sport and was a work of Coubertin. Starting in 1924, more works were entered into the competition; however, the level of quality was extremely low. No famous artist took part in the competition. As the program was constantly changing, it was difficult to shape its profile. In 1949, it was decided that the competition would be abolished, which was fortunate for the strictly sporting nature of the Games. In 1952, it was declared that any possibility to maintain the competition was unfeasible. The president of the IOC, Sigfrid J. Edstrom, stated that "Artistic competitions are contrary to the spirit and letter of Olympic amateurism because the artists participating in them are professionals" (given as: W. Lipoński, 1987, pp. 235-236). The main fully subconscious and completely legitimate reason for breaking the above doubtful interdisciplinary collaboration is the inability to connect it to the ancient relationship that occurred between art and sports which was inspired by a divine spark that inspired the pursuit of creative excellence and immortality. If Coubertin's competitions were maintained, then we would be faced with some strange unilateral form of "ordination", "refinement", and "ennoblement" (Lipoński, 1987, p. 235), constantly underlining the fact that, regardless of Coubertin's will (the author of the three expressions above), sports has a frailty of values and social status in comparison to art. In this instance, the French Baron was referring not so much to the mutual inspiration and common path towards ecstatic achievement and transcendental experiences, but rather to divine and ideal values. The instrumental arts were treated in an axiological context, which added value to the Olympics and the Olympic Games. The axiological dissonance among the indicated activities is currently too large such that the dissonance between their main assumptions, the values, and the associated evaluations could ever be neutralized.
} 
Alternatively, Pierre de Coubertin, who was aware of the impact of beliefs and religious institutions, earnestly strove to make the Olympic movement and modern Olympic Games specific to the church and religion in a broad sense, or, in other words, to make them secular. He treated Olympic sports as a "modern religion" (Parry, 2007, pp. 205-207) and contemporary Olympians as "the religio athletae" (Parry, 2007, pp. 205-207).

He created a doctrine (i.e., specific teachings) in the form of neo-Olympic ideology, which included the assumptions of the sports pedagogy that he initiated (published in 1919 as Pedagogie sportive), and from which he establishes a sense of Olympic education. It also refers to the institutional structures of the Olympics, centralized and hierarchical movements such as in Catholicism, organizations made up of unquestionable doctrinal and ceremonial oracles ("rituals"), the International Olympic Committee and their subordinates, the National Olympic Committees, which are specific despite the obvious difference between "The Vatican" and the national "churches" related to it.

The indicated organization, doctrine, forms of cults, and ethical assumptions refer to the principles of fair play. These testified that Baron de Coubertin undoubtedly sought to assign values to the games that went beyond the simple, strictly physical, and regulated competition and its rules.

The purpose was to serve not only the "secular-holy forms of cult", but also the opening and closing of the Olympic Games and the ceremonies for presenting the medals and the oaths.

The modern Olympic Games are nothing more than sports.

At the beginning and the end of the Olympic Games, giant choreographed stage performances are shown with harmoniously placed singing performances that are usually full of colorful mosaic lights with fragments of various compositions from popular culture, a compilation adapted to the aesthetic and cognitive level of the stadium supporters - the average and undiscriminating recipients of mass culture.

Pierre de Coubertin suffered a spectacular defeat, as he did not manage to imbue the Olympic Games with religious or artistic values. The Games are, in truth, a festive occasion (in relation to the profanum Iprofane/ of daily life), significant only to those who are interested in groups of athletes, trainers, officials, sponsors, supporters, the national Olympic committee, or the rankings of different countries.

However, the presented works of art can at most be associated with the sports theme. There is no longer an organic relationship between art, sports, and religion as there was in ancient Greece. The current association between Olympic sports and art is, despite the attempts to enhance the status of the Games, a simulated process which creates a clear dissonance with substantive ontological and axiological impact.

During the aforementioned ceremony, people such as members of the National Olympic Committee and representatives of players and referees usually make a few laconic statements and an oath to the Games ${ }^{8}$.

The ceremonial and ideological importance of the Games is lowered by the clear falsity of assessments of the gravity, force, and scope of their influence. The representatives of the IOC (International Olympic Committee) and the local organizers of any given Games emphasize that the Olympic Games, including the opening and closing ceremonies, have a unique effect on the emotional and spiritual state of current world events. This is confirmed and the impact is multiplied by the various journalistic comments and common points of view which saturate popular culture.

Meanwhile, the world and its States, nations, and individuals operate autonomously during this time in a socio-cultural rhythm doing activities of a daily, economic, professional, educational, familial, political, ideological, religious, and artistic nature.

All offices, universities, schools, kindergartens, armies, hospitals, concert halls, theaters, and cinemas function at this time as usual. Numerous television channels, apart from the ones that transmit the Games

${ }^{8}$ Parry adds that "The Olympic rings, the Olympic flag, the Olympic anthem, the Olympic address, the Olympic Oath, the carillon of bells, fanfares, ritual processions, choir-singing, banners, pigeons, symbolic light, architecture (...) are all designed to heighten the feelings and experiences of participants and observers alike, to exploit symbolic meaning and to elevate the importance and significance of the occasion" (Parry, 2007, p. 209). 
in a given country, show their complete detachment from the Olympic Games with routine programs. Politicians, with the exception of those from the host country of the Games, do not concern themselves in general with the Games if they do not want to cause tension, conflicts, wars, boycotts, or stimulate terrorist attacks.

The majority of sports disciplines, including the most popular spectator sports and the most lucrative ones, are not present or are only present in a rudimental way at the Games. The Olympic Games are not anything extraordinary; their primary objective is to determine the most skilled player in a given sport.

It is proclaimed during the Games that the event is something exceptional in the lives of today's youth, and that they are taking part amongst the best. In fact, this is false, not only in the context of the entirety of the sporting environment, but also regarding the Games' relationship with youth who do not take part in professional sports or people who are primarily interested in education, medicine, business, philosophy, or artistic careers. These are youth who fulfill their choices outside of professional sports. This is true for the overwhelming majority of youth in general.

Spiritualization that is based on false premises is not true spiritualization. It is a deformation of spiritual reality that can lead to alienation and become an opiate of the masses. This is the opiate of the youth who are unilaterally indoctrinated in propaganda and ideology.

The attribution of the modern Games to over-praxeological (over-utilitarian and over-pragmatic) qualities and functions, such as those of a missionary, humanitarian, and deeply spiritual nature, is misplaced and unnecessary.

The most important issue for athletes in the Games to is achieve the goal of variously understood sporting success. The remainder of the expectations, aspirations, dreams, and needs are for the players, trainers, sports associations, national Olympic committee, and even the supporters of a secondary or tertiary nature.

Only athletes that qualify during the elimination rounds or receive a minimum score are able to take part at the Olympics. This is a measurable or discretionary result that allows them to take part in the Games. They do not make it onto the Olympic teams on the basis of specific character traits, e.g., honesty, modesty, nobility, selflessness, discipline, or the creation of valuable, inspiring, and innovative social ideas of ethical principles. In this case, the deciding factors are their competence and professional success.

As an example, Polish Olympians, like competitors in other countries, receive a bonus for placing high in competitions (from first to third place), and also have a monthly remuneration for life (in Poland, after 35 years of age). It is irrelevant to the Polish Olympic Committee if athletes rank lower than third place, as these authorities are of the opinion that lower-ranking athletes will be quickly forgotten.

In the situations mentioned above, the view that the Olympic Games are more than just sports is not confirmed. All that is confirmed is that athletes, especially those who are highly ranked in competitions, are highly paid by state and non-governmental institutions in a given country, as well as by private sponsors. Olympic sports, like other forms of competitive, professional, or spectator sports, reveal clear reductionist qualities, reducing the impact and scope of human and spiritual demands.

In my opinion, there has been a transparent and irreversible retreat or even break within deep spirituality. There is a clear instrumentalization of Olympic sports. The IOC authorities and national Olympic committees that prepare for the Games focus predominantly on ensuring the optimal efficiency of the organization, maximum viewership, and commercial success of the Games, as well as their high revenues from ticket sales, advertising, and television and radio broadcasting. The athletes and national Olympic committees focus on the maximum number of medals that can be won and on achieving the optimal position in the medal rankings.

The Olympic movement adapts itself, sometimes with difficulty, to the guiding principles of supranational and transnational, e.g., continental and global sporting organizations, taking into account the provisions and principles that are in force. This refers to many spectator disciplines in the field 
of professional sports, e.g., football, ice hockey, athletics, tennis, and volleyball. For example, players representing the NBA in the United States were not subject to doping controls during the Olympic Games.

\section{Spiritualization and the ethical mission of sports}

In a subsequent approach to spirituality ${ }^{9}$, Samuel Robinson discusses three principle areas related to awareness, dignity, and development. He points to the:

"awareness and appreciation of the other (including the self, the other person, the group, the environment and, where applicable, deity). The capacity to respond to the other. This involves putting spirituality into practice, embodying spirituality, and thus the continued relationship with other. Developing significant life meaning based upon all aspects of awareness and appreciation of and response to the other" (Robinson, 2007a, p. 24).

Jim Parry comments on the above statement and pays attention to the fact that Robinson uses it to imply that Coubertin did not consider the reality of Olympism; rather, he considered the issues from a formal point of view, as a typical religion that aimed to compete with Christianity or Buddhism for the soul. In fact, it was spirituality in the form of a moral movement whose goal was the potential scope of excellence (Parry, 2007, pp. 209-210). I believe that we thus have to deal only with the common and propositional forms of spirituality which have a moralizing impact, although our intentions otherwise may be noble.

Some theorists of physical education and sports, followers in the footsteps of the French Baron, and even professional athletes give importance to some extra ethical tasks which are allegedly the most important in their profession and that go beyond the main objective of earning for their core profession. They indicate that it is a calling, independent of their knowledge and will regarding the topic, that allows them to meet the needs of the mission of which the aim in general is to spread moral good.

These theorists refer in this case (probably unintentionally) to the ethical views of Socrates, treating humankind principally as homo ethicusa. Socrates recognizes philosophy as wisdom (as well as knowledge) primarily concerning moral virtue. This one-sided form of ethical intellectualism and the associated archaic and superficial current anthropological reductionism is, in my opinion, impossible to maintain from a modern anthropological and human philosophical point of view, including pluralism, relativism, liberalism, panthareism, and ethical chaos (Kosiewicz, 2014a, pp. 5-22; Kosiewicz, 2015, pp. 75-87).

Incidentally, the concept of good is a concept of an intuitive nature. In truth, according to Plato, we deal with one intuitive perception of the concept of universal good (which is the highest in the hierarchy of eternal ideas); it is nevertheless accompanied by a countless number of ideas which more or less conflict and compete against each other, in comparison to other concretizations in the form of various normative ethics. They confirm the objectivity and universality of good as being ideal in the indicated terms. In contrast, they also affirm discretion, pluralism, relativism, and chaos within the ever-changing (moral panthareism) objectified set of normative ethics.

Taking this into account, an athlete can fulfill this need for good (moral principles), just as they intuitively experience it. They can relate it to the assumptions and regulations of any given discipline in which they partake, as long as it is not against the rules and does not interfere with the course of the competition. Therefore, there is no question of an extraordinary mission, a calling, or an extension of one universal and objective moral good and the normative ethics associated with it.

\footnotetext{
${ }^{9}$ In a subsequent attempt to define spirituality (presented more in the spirit of spiritualism), Robinson states that it refers to "the practice and outworking of the spirit and the ways in which it developed, with its different aspects and relationships connected, sustained and understood. As we shall see, this may involve the spirituality of an individual or that which is developed in and through the disciplines and practices of a group or team. It is often a combination of both. Essentially, then, spirituality is relation and action centered, and about making connections with these different aspects of life" (Robinson, 2007a, p. 24).
} 
An attempt at the spiritualization (in the context of spiritualism) of the modern Olympic Games through the introduction of moralistic, excessive, and unilateral moral disposition regarding the athletes the expectations that go beyond their profession - is an artificial phenomenon and is fortunately marginal.

In actuality, it is a noble attempt, but it is located outside of the daily and Olympic professional Agon. This excessive and utopian spiritualization applies only to the abovementioned theorists. Indeed, only in their internal unrealistic, hypostatic, and external relationship to sports may moral spiritualization arise.

On one hand, they arguably attempt to enhance the knowledge of the possible interpretations of the principles and moral behavior in Olympic relations; on the other hand, they negatively affect them, not only when they consider their own opinions as being righteous, but particularly when they try to impose them on others and force others to accept them.

There is also the case when we hear evaluations of journalistic comments that accompany the Games (which is typical for reporting from both national and international championship competitions). A sport commentator was negatively evaluated by a known theorist of physical education and sports, who accused him of a noticeable shortage of moral consideration in his comments. He points out that they have become a testimony "to the ignorance of sports writers".

This criticism is exaggerated and reflects expectations that are too high. Sports journalists are not prepared from a professional angle to submit moral considerations. Moreover, they do not have to be familiar with the controversial moral sentiments of specific didactic or academic co-workers, not to mentions. That they have no obligation to share or distribute their comments. Furthermore, the statements of sports journalists primarily present a common and popular point of view that is diversified in relation to the forms of these statements.

Journalists fulfill other general social needs in a manner unscholarly in nature, just as politicians, sailors, chroniclers, playwrights, and steel workers do. They are professionals and specialists in one specific area. They adapt to the expectations of society, employers, supporters, athletes, or other people that are interested in sports, including those who are not involved in sports. All journalists are entitled to their own view on sports and may treat them as an expression of mass culture. They are not, however, professional moralists, as are, for example, Roman Catholic priests. Neither are they called - like Immanuel Kant or any of the citizens of his noumena republic - to implement some unclear categorical imperatives, suspended high in a starry sky. The journalists are neither a device nor a necessary distributor of sports. It is not this transcendentally situated, formal, abstract, and at the same time falsely justified categorical imperative, that is the most important. It is specific human activity that matters, as well as the way this activity meets specific needs, for example, aesthetic ones in arts, healing in medicine, transport in railways or aviation, and competitive needs in competitive sports. The accompanying discretionary, relativistic, and pantheistic (variable) moral assumptions are not the paramount objective; at best, they are an additional element, whose necessity is questionable for the proper actualization of a given occupation, for example that of a painter, a doctor, a pilot, or an athlete ${ }^{10}$.

\section{REFERENCES}

Baker, W.J. (2000). Gods and Games - Religious Aspects of the Modern Olympics. In If Christ Came to the Olympics. Sydney, Australia: UNSW Press.

Banek, K. (2003a). Kobiety w kulcie Dionizosa/Women in the Cult of Dionysus/. In Nomos, Quarterly Religious Expert Review, 41/42.

Banek, K. (2003b). Scytowie wobec kultu Dionizosa w Olbii /The Scythians Against the Cult of Dionysus in Olbia/. In Nomos, Quarterly Religious Expert Review, 41/42.

\footnotetext{
${ }^{10}$ I decided to delete from the text the names of the physical and sport education theorists - those who describe sporting activities as a specific moral mission - as these are the people who I am arguing against. I do not intend to offend any of these persons.
} 
Baxton, R. (1999) (Ed.), From Myth to Reason? Studies in the Development of Greek Thought. Oxford: Oxford University Press.

Benisz, H. (2001). Nietzsche i filozofia dionizyjska /Nietzsche and Dionysian Philosophy/. Warsaw: Wydawnictwo AWF.

Bravo, B., Wipszycka, E. (1988). Historia starożytnych Greków /History of the Ancient Greeks/, 1. Warsaw: PWN.

Coakley, J.J. (1986). Sport and Religion, Is it a Promising Combination? In Sport and Society, $3^{\text {rd }}$ Edition, St. Louis, Missouri: Times Mirror/Mosby, College Publishing.

Diogenes Laertius (1925b). Lives of eminent philosophers, 2 (R.D. Hicks Trans.). London: Heinemann.

Eitzen, D.S., Sage, G.H. (1989). Sport and Religion. In Sociology of North American Sport, $4^{\text {th }}$ Edition.

Eliade, M. (1954). The myth of the eternal return. (Willard R. Trask Trans.). New York: Harper \& Brothers Publishers.

Eliade, M. (1965). Myth of the Eternal Return or the Cosmos and History. New York: Harper Torchbooks.

Eliade, M. (1978, 1; 1982, 2, 1985, 3). A history of religious ideas. Chicago: The University of Chicago Press.

Eliade, M. (1997). Sacrum, mit, historia. Wybór esejów /Sacrum, myth, history: A collection of essays/. Warsaw: PWN.

Enger, D.J. (2003). Should Sports be Used as a Tool for Ministry. Retrieved from http://www.tiu.edu/cmx/seniors03/enger.pdf

Eurypides (2007). The Bacchae. In Eurypides.

Gansiniec, R. (1934). Dionysos i Mainady /Dionysos and Maenads/. In Przegląd historyczny /Historical Overview/, 2.

Godwin, J. (1981). Mystery Religions in the Ancient World. Cambridge: Harper \& Row.

Gołaszewska, M. (1985). Artistic and aesthetic values in the axiological situation. In Philosophica, 36.

Graves, R. (1993). The Greek Myths. London: Penguin Books.

Guttman, A. (1992). From Ritual to Record. In Shirl J. Hoffman (Ed.), Sport and Religion. Champaign, Illinois:Human Kinetics Books.

Hammond, N.G.L. (1986). A History of Greece to 322 BC. Oxford: Oxford University Press.

Head, B.V. (1911). Historia Numorum. Oxford: Not in Copyright.

Hoffmann, H. (2003a). Tadeusz Zieliński (1959-1944) i jego interpretacja motywów dionizyjskich w tragedii greckiej /Tadeusz Zieliński (1959-1944) and his interpretation of the Dionysian motives in Greek tragedy/. In Nomos, Quarterly Religious Expert Review, 41/42.

Hoffmann, H. (2003b). Ryszard Gansiniec (1888-1958) i jego interpretacja dionizyjskiego szału menad /Richard Gansiniec (1888-1958) and his interpretation of the Dionysian maenad frenzy/. In Nomos, Quarterly Religious Expert Review, 41/42.

Jaeger, W. (1964). Paideia. Oxford: Basil Blackwell.

Judycki, J. (1997) Duch - materia /Spirit-bodily matter/. In J. Herbut (Ed.), Leksykon filozofii klasycznej /Lexicon of Classical Philosophy/. Lublin: Towarzystwo Naukowe KUL.

Kierkegaard, S. (2006). Fear and Trembling. Cambridge: Cambridge University Press.

Kant, I. (1984a). Krytyka praktycznego rozumu /Critique of Practical Reason/. Warsaw: PWN.

Kant, I. (1984b). Uzasadnienie metafizyki moralności /Groundwork for the Metaphysics of Morals/. Warsaw: PWN.

Kant, I. (2012). Groundwork for the Metaphysics of Morals. Cambridge: Cambridge University Press.

Kerenyi, K. (1976). Dionysos: Archetypal Image of Indestructible Life. Princeton: Princeton University Press.

Kosiewicz, J. (1998). Myśl wczesnochrześcijańska i katolicka wobec ciała /Attitude of Early Christian and Catholic Thought towards the Body/. Warsaw: AWP Witmark.

Kosiewicz, J. (2000). Rene Girard - geneza religii i kultury /Rene Girard: the development of religion and culture/. In Bóg, cielesność i miłość /God, physicality, and love/, (pp. 39-62). Warsaw: Aletheia.

Kosiewicz, J. (2004). Filozoficzne aspekty kultury fizycznej i sportu /Philosophical Aspects of Physical Culture and Sport/. Warsaw: Wydawnictwo BK.

Kosiewicz, J. (2005). Tourism and Sacrum. In European Journal for Sport and Society, 2, 7-12.

Kosiewicz, J. (2006). Rekreacja fizyczna w zwierciadle filozofii /Physical recreation in the face of philosophy/. In A. Dąbrowski (Ed.), The basis theory of movement recreation. Warsaw: Almamer. 
Kosiewicz, J. (2008). The Anthropological Background of Philosophical Reflection on Nature and Tourism. In European Journal for Sport and Society, 5(2), 143-151.

Kosiewicz, J. (2013). Teatr poza teatrem. Yorick /Theatre outside the theatre: Yorick/, 35. Electronic edition of the theatrical writings, no pagination.

Kosiewicz, J. (2014a). The Normative Ethics and Sport: A Moral Manifesto. In Physical Culture and Sport. Studies and Research, 62, 5-22. DOI: 10.2478/pcssr-2014-0008.

Kosiewicz, J. (2014b). Western Sport and Spiritualism. In Physical Culture and Sport. Studies and Research, 62, 74-82. DOI: $10.2478 /$ pcssr-2014-0013.

Kosiewicz, J. (2014c). Sport and Social Deviations: Prognostic Attitude. In Physical Culture and Sport. Studies and Research, 62, 64-73. DOI: 10.2478/pcssr-2014-0012.

Kosiewicz, J. (2014d). The Body, Sex, and Erotic Love in the Context of Plato's Philosophy of Culture. In S. Bouduris, \& K. Kalimitizis (Eds.), Issues in Human Relations and Environmental Philosophy, (pp. 144-175). Athens: International Center of Greek Philosophy and Culture \& KB.

Kosiewicz, J. (2014e). Philosophy in the crucible of etymology: Madness and cognition. In S. Bouduris, \& K. Kalimitizis (Eds.), Issues in Human Relations and Environmental Philosophy, (pp. 176-211). Athens: International Center of Greek Philosophy and Culture \& KB.

Kosiewicz, J. (2015). Why Pluralism, Relativism, and Panthareism: An Ethical Landscape with Sport in the Background. In Physical Culture and Sport. Studies and Research, 66, 75-87. DOI: 10.1515/pcssr-2015-0015.

Kosiewicz, J. (2015). Sport i sztuka - różnice i zbliżenia teatralne /Sports and Arts: Theatrical differences and similarities/. In M. Zowisło, J. Kosiewicz (Eds.), Sport and tourism, a reflection of social values, (pp. 111-136). Kraków: Wydawnictwo Akademii Wychowania Fizycznego.

Krawczyk, Z. (1970). Natura, kultura, sport. Kontrowersje teoretyczne /Nature, culture, and sports: Theoretical controversies/. Warsaw: PWN.

Krokiewicz, A. (2000). Studia orfickie /Orphic studies/. In Studia orfickie. Moralność Homera i etyka Hezjoda /The Orphic Studies: Homer's Morality and Hesiod's Ethics/. Warsaw: Aletheia.

Lipoński, W. (1987). Humanistyczna encyklopedia sportu /A humanistic encyclopedia of sport/, (pp. 235-236). Warsaw: Sport i Turystyka.

Lippki, S. (2003). Pochodzenie kultu Dionizosa. Przegląd głównych teorii /The origin of the cult of Dionysus: Overview of the main theories/. In Nomos, Quarterly Religious Expert Review, 41-42.

Łanowski, J. (2007). Wstęp /Introduction/. In Eurypides. Tragedie /Eurypides: Tragedies/, 4. Warsaw: Pruszyński i S-ka.

Nicoll, A. (1950). World Drama. New York: Harcourt, Brace \& World, Inc.

Nietzsche, F. (1999). The Birth of Tragedy and Other Writings. Cambridge: Cambridge University Press.

Otto, R. (1968). Świętość /The Idea of the Holy /. Warsaw: PWN.

Otto, W.F. (1965). Dionysus: Myth and Cult (Transl. Indiana University Press). Bloomington: Indiana University Press.

Parry, J. (2007). Spirituality: A working definition. In Sport and Spirituality. An Introduction, (pp. 201-214). London and New York: Routledge, Taylor \& Francis Group.

Pawlik, D. (2010). Rytualne zdobienia ciała Maorysów. Sztuka Ta-moko /Maori ritual body embellishments: Art Tamok/. In Antypodes, 2, 56-61.

Pawlik, D. (2011). Maori ritual body embellishments. In IDO Movement for Culture, 11, 111-116.

Plato (1984). Uczta /Symposium/. In Uczta, Eutyfron, Obrona Sokratesa, Kriton, Fedon /Symposium, Eutryphro, Apology, Kriton, Phadon/, (pp. 48-162). Warsaw: PWN.

Plato (1993). Fajdros /Phaedrus/. Warsaw: PWN.

Plato (1997). Państwo, Prawa (VII Ksiąg)/The Republic, 1-7/. Kęty: ANTYK Publishers, Marek Drzewiecki.

Rhode, E. (1966). Psyche; the cult of souls and belief in immortality among the Greeks (W.B. Hills, Trans.). New York: Harper \& Row.

Robinson, S. (2007a). Spirituality: A working definition. In Sport and Spirituality. An Introduction, (pp. 22-37). London and New York: Routledge, Taylor \& Francis Group. 
Robinson, S. (2007b). Spirituality: A story so far. In Sport and Spirituality. An Introduction, (pp. 7-21). London and New York: Routledge, Taylor \& Francis Group.

Saint Sing, S. (2004). Spirituality of Sport, Balancing Body and Soul. Cincinnatti, Ohio: St. Anthony Messenger Press.

Skrzypińska, K. (2004). Czy duchowość jest tożsama z religijnością? Nowe perspektywy badawcze /Is spirituality synonymous with religion? New research perspectives/. In Religious Expert Review, 4(214), 13-25.

Sokołowski, F. (1936). Kult Dionizosa w Delfach /Cult of Dionysus in Delphi/. Lwów: Towarzystwo..

Srebrny, S. (2003). Teatr grecki i polski /Greek and Polish Theater/. Warsaw: PWN.

Ventris, M., Chadwick, J. (1973). Documents in Mycenean Greek. Cambridge. Cambridge University Press.

Vernant, J.P. (1982). The Origins of Greek Thought. Ithaca: Cornell University Press.

Vernant, J.P. (1983). Myth and Thought Among the Greeks. London: Routledge and Kegan Paul.

Vlastos, G. (1965). The Disorderly Motion in the Timaeus. In R. Alen (Ed.), Studies in Metaphysics. London. Routledge and Kegan Paul.

Vlastos, G. (1989). The Individual as Object of Love in Plato. In A. Soble (Ed.), Eros, Agape and Philia: Readings in the Philosophy of Love. St. Paul, MN: Paragon Press.

Wargacki, S.A. (2003). Dionizos i Śiwa - bogowie uniesienia i ekstazy /Dionysus and Shiva: The gods of rapture and ecstasy/. In Nomos, Quarterly Religious Expert Review, 41/42.

Zaruski, M. (1958a). Powrót /Return/. In Na bezdrożach tatrzańskich. Wycieczki, wrażenia, opisy /Wilderness of the Tatra Mountains: Tours, impressions, and descriptions/. Warsaw: SiT.

Zaruski, M. (1958b). Nowa grota w Giewoncie/New Grotto on the Giewont/. In Na bezdrożach tatrzańskich. Wycieczki, wrażenia, opisy /Wilderness of the Tatra Mountains: Tours, impressions, and descriptions/. Warsaw: SiT.

Zaruski, M. (1958c). Organizacja Tatrzańskiego Ochotniczego Pogotowia Ratunkowego/The Tatra Voluntary Rescue Service Organization/. In Na bezdrożach tatrzańskich. Wycieczki, wrażenia, opisy /Wilderness of the Tatra Mountains: Tours, impressions, and descriptions/. Warsaw: SiT.

Ziętek, D. (2003). Taniec i inne obrzędy dionizyjskie oraz ich społeczno-psychologiczne funkcje /Dance and other Dionysian rites and their socio-psychological functions/. In Nomos, Quarterly Religious Expert Review, 41/42.

AUTHOR'S ADDRESS: Jerzy Kosiewicz

Department of Philosophy, Chair of the Social Sciences

Josef Pilsudski University of Physical Education in Warsaw

Marymoncka 34

00-968 Warsaw, Poland

Email: jerzy.kosiewicz@awf.edu.pl

Received: 11 September 2015; Accepted: 28 October 2015 